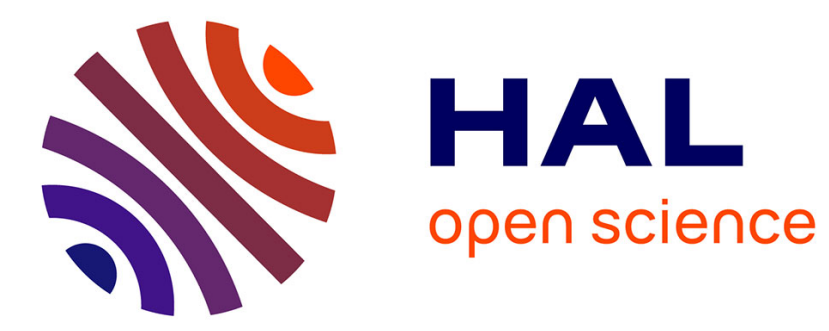

\title{
Experiences with recombinant FVIIa in the emergency treatment of patients with autoimmune thrombocytopenia: a review of the literature
}

\author{
A. Salama, M. Rieke, H. Kiesewetter, M. Depka
}

\section{- To cite this version:}

A. Salama, M. Rieke, H. Kiesewetter, M. Depka. Experiences with recombinant FVIIa in the emergency treatment of patients with autoimmune thrombocytopenia: a review of the literature. Annals of Hematology, 2008, 88 (1), pp.11-15. 10.1007/s00277-008-0608-3 . hal-00477982

\section{HAL Id: hal-00477982 \\ https://hal.science/hal-00477982}

Submitted on 30 Apr 2010

HAL is a multi-disciplinary open access archive for the deposit and dissemination of scientific research documents, whether they are published or not. The documents may come from teaching and research institutions in France or abroad, or from public or private research centers.
L'archive ouverte pluridisciplinaire HAL, est destinée au dépôt et à la diffusion de documents scientifiques de niveau recherche, publiés ou non, émanant des établissements d'enseignement et de recherche français ou étrangers, des laboratoires publics ou privés. 


\title{
Experiences with recombinant FVIIa in the emergency treatment of patients with autoimmune thrombocytopenia: a review of the literature
}

\author{
A. Salama $\cdot$ M. Rieke $\cdot$ H. Kiesewetter $\cdot$ M. von Depka
}

Received: 1 April 2008 /Accepted: 28 August 2008 / Published online: 12 September 2008

(C) Springer-Verlag 2008

\begin{abstract}
Patients with severe and refractory autoimmune thrombocytopenia (ITP) have significant morbidity and mortality rates. Currently, high-dose methylprednisolone and/or high-dose IVIgG are recommended for the emergency treatment of such patients with uncontrolled bleeding. However, some patients do not immediately respond to these therapeutic regimes and may require additional treatment. Recombinant activated FVIIa (rFVIIa) is a prothrombotic agent that appears to be useful in the treatment of patients with life-threatening bleeding. It has also been used in the treatment of several patients with thrombocytopenia. We administered rFVIIa into a patient with refractory ITP and performed a systemic review of all published reports to assess the available evidence on the efficacy and safety of this drug in patients with ITP. The results indicate that rFVIIa may help in the emergency treatment of patients with ITP who do not respond to other therapies.
\end{abstract}

Keywords ITP · rFVIIa · Bleeding · Thrombocytopenia . Hemostasis $\cdot$ Hemorrhage

\footnotetext{
A. Salama $(\bowtie) \cdot H$. Kiesewetter Institut für Transfusionsmedizin, Charité-Universitätsmedizin Berlin, Augustenburger Platz 1, 13353 Berlin, Germany

e-mail: abdulgabar.salama@charite.de

M. Rieke $\cdot$ M. von Depka

Werlhof Institut,

Karl-Wiechert-Allee 1a,

30625 Hannover, Germany
}

\section{Autoimmune thrombocytopenia}

Autoimmune thrombocytopenia (ITP) is an immune-mediated disorder that may result from the production of glycoprotein specific autoantibodies, leading to platelet destruction by macrophages $[25,31,32,41]$. The incidence of ITP ranges between 50 and 100 new cases per million each year, with roughly $50 \%$ of these cases occurring in children. It may occur with or without association to other diseases, i.e., infections particularly in children, autoimmune diseases, and malignancies. In general, the illness is acute and resolves spontaneously in children but remains chronic in most affected adults $[12,13,16]$.

\section{Clinical picture and therapy}

ITP is characterized by low platelet counts, bleeding, and/or a risk of bleeding. Most patients with ITP primarily tolerate their thrombocytopenia relatively well and do not require specific treatment unless significant bleeding develops or the patient is subjected to a procedure associated with a risk of bleeding, i.e., surgery [7, 13, 18, 36, 37]. Patients with ITP have various therapeutical options which include corticosteroids, IVIgG, anti-D, and splenectomy. Approximately $30 \%$ of patients are refractory to these treatments. This group does not or only poorly responds to subsequent treatment and has a significantly higher risk of morbidity and mortality [30, 36, 37]. In addition, some of these patients suffer from severe and refractory disease and may develop life-threatening bleeding that requires immediate intervention. In such cases, emergency treatment includes high-dose IVIgG (1 g/kg/days for one-three consecutive days) and/or high-dose methylprednisolone (1-2 g/days for one-three consecutive days) $[7,13,18,30,37]$. However, 
this treatment is not invariably effective, and a significant increase in the platelet count is usually not achieved until 48 to $72 \mathrm{~h}$ following initiation of therapy $[9,23]$. Due to these uncertainties and the fact that serious bleeding cannot be immediately controlled in some cases, additional agents are sometimes required to stop bleeding. Platelet transfusion is infrequently administered in such cases, although there is no consensus regarding the optimal dose and strategy of treatment $[1,4,6,10,11,14,47]$. Thus, there is indeed a need for an abruptly effective agent for the treatment of patients with ITP and life-threatening bleeding.

\section{Activated recombinant FVII}

Recombinant FVII (rFVIIa) has been demonstrated to potentially stop bleeding in patients with hemophilia, severe thrombocytopenia, and in patients without coagulopathy $[17,29]$. We have administered rFVIIa into a 17year-old female who had a refractory ITP and a significant bleeding tendency. The drug was administered at a dose of $120 \mu \mathrm{g} / \mathrm{kg} 10 \mathrm{~min}$ prior to and two times after a wisdom teeth extraction including osteotomy (Tables 1 and 2). Although a local treatment with tranexamic acid and fibrin was performed, we believe that rFVIIa was the main factor for achieving a satisfying hemostasis. Although there is evidence that rFVIIa may have been used in many patients with ITP (personal communication with various physicians), to date, only few reports have addressed this question. A systematic review of all published clinical studies led to the identification of a total of 15 reports on rFVIIa and ITP (Table 1). In these studies, at least 17 patients (six children and 11 adults) with ITP were found to have been treated with rFVIIa. All these patients were defined as being refractory to different therapies. Unfortunately, prior to or during administration of rFVIIa, the platelet count was not monitored in most cases. In addition, all of the patients reported in these studies immediately received at least two additional types of drugs and/or were splenectomized (Table 2). Furthermore, the doses of rFVIIa which were utilized in those studies were highly variable and ranged between a single dose of $50 \mu \mathrm{g} / \mathrm{kg}$ to more than 80 doses of $122 \mu \mathrm{g} / \mathrm{kg}$. Nevertheless, we and all other reports with one exception came to the mutual conclusion that $\mathrm{rFVIIa}$ is useful in the management of uncontrolled bleeding in ITP (Table 2). In one patient (no. 17), rFVIIa showed only diminished or no effect, and bleed could not be stopped, ultimately resulting in death. Interestingly, serious side effects were not reported to be observed in any of the patients. In addition, two patients deceased despite the cessation of bleeding (Table 2).

\section{How rFVIIa may improve hemostasis in ITP}

The question as to how and to what extend rFVIIa has stopped bleeding in the reported patients with ITP remains speculative. On the one hand, this prothrombic agent was

Table 1 Studies reporting the administration of activated recombinant FVII to ITP patients

\begin{tabular}{llllll}
\hline Report & Patient (no.) & Age (years) & Sex & pl $\times 10^{3} / \mu l^{\mathrm{a}}$ & Prior treatment \\
\hline Minniti et al. [33] & 1 & 11 & $\mathrm{M}$ & 8 & IVIgG, Anti-D, Steroids \\
& 2 & 8 & $\mathrm{M}$ & 7 & $?$ \\
Klamroth et al. [26] & 3 & 45 & $?$ & $10-15$ & $?$ \\
Gerotziafas et al. [19] & 4 & 75 & $\mathrm{M}$ & 9 & Chemotherapy, Pred \\
Waddington et al. [45] & 5 & 68 & $\mathrm{~F}$ & 17 & Pred \\
Culic [15] & 6 & 8 & $\mathrm{~F}$ & 13 & $?$ \\
Hadacova and Hoch [21] & 7 & 36 & $\mathrm{M}$ & $?$ & Steroids \\
Serban et al. [40] & $8(?)$ & $?$ & $?$ & $?$ & $?$ \\
Virchis et al. [43] & 9 & 51 & $\mathrm{~F}$ & 1 & Splx, Steroids, Aza \\
Vyhovs'ka et al. [44] & $10(?)$ & $?$ & $?$ & $?$ & $?$ \\
Busani et al. [8] & 11 & 52 & $\mathrm{~F}$ & 30 & Anti-CD 20 \\
Barnes et al. [3] & 12 & 16 & $\mathrm{~F}$ & $4 ?$ & IVIgG, Steroids, Cyclosp, BMT, Anti-CD, Anti-TNF $\alpha$ \\
Morath et al. [35] & 13 & 46 & $\mathrm{M}$ & 54 & Pred, Tacrolimus, IVIgG \\
Wrobel et al. [46] & 14 & 14 & $\mathrm{M}$ & $<10$ & Pred, Dexa, IVIgG, Anti-CD 20, Cyclosp Pred, MP, IVIgG \\
& 15 & 7 & $\mathrm{M}$ & 10 & \\
Aguilar and Lucia [2] & 16 & 78 & $\mathrm{M}$ & $?$ & Pred, IVIgG \\
Baxter et. al [5] & 17 & 70 & $\mathrm{~F}$ & $<10$ & Splx, Steroids \\
This study & 18 & 17 & $\mathrm{~F}$ & 2 & Pred, IVIgG, Vinc, MM, Dexa, Steroids \\
\hline
\end{tabular}

pl Platelet, Pred prednisolon, Splx splenectomy, Aza azathioprine, Cyclosp cyclosporine, BMT bone marrow transplantation, Dexa dexamethasone, $M P$ methylprednisolone, $M M$ Mycophenolatmofetil

${ }^{\mathrm{a}}$ The platelet count has not been invariably determined prior to FVIIa administration. 
Table 2 Administered rVIIa into the reported patients with bleeding and/or bleeding risks

\begin{tabular}{|c|c|c|c|c|}
\hline Patient & $\begin{array}{l}\text { Treatment prior to/during } \\
\text { rFVIIa administration }\end{array}$ & Reason for treatment & rFVIIa $(\mu \mathrm{g} / \mathrm{kg}) / \mathrm{time}$ & Outcome \\
\hline 1 & PI, RBCs, FFP, Cry/Splx & $\mathrm{ICH}$ & $3 \times 50,2 \times 75,1 \times 90 / 36 \mathrm{~h}$ & No further bleeding \\
\hline 2 & $\begin{array}{l}\text { IVIgG, RBCs, Vinc, MP/Pl } \\
\text { IVIgG, Splx }\end{array}$ & Hematuria & $1 \times 50$ & No further bleeding \\
\hline 3 & Pred, IVIgG & Parathyroid op & $\begin{array}{l}1 \times 90 \text { (bolus), } 45 /(2 \mathrm{~h})^{\mathrm{b}} \text { day } 1,45 / \\
(3 \mathrm{~h})^{\mathrm{b}} \text { day } 2,45 /(4 \mathrm{~h})^{\mathrm{b}} \text { day } 3\end{array}$ & $\begin{array}{l}\text { Satisfying hemostasis during } \\
\text { surgery }\end{array}$ \\
\hline 4 & Dexa, IVIgG, Pl, Pl, RBCs & Bleeding & $1 \times 90$ & $\begin{array}{l}\text { Bleeding was stopped, Splx } \\
\text { without complication }\end{array}$ \\
\hline $5(\mathrm{Jw})$ & $\begin{array}{l}\text { Pred, IVIgG, MP, Splx, aa, } \\
\text { Tranex, Cry }\end{array}$ & Bleeding & $3 \times 90$ & $\begin{array}{l}\text { Hemostasis was achieved, but } \\
\text { the patient died }\end{array}$ \\
\hline 6 & Steroids, Pl, Tranex & Epistaxis & $1 \times 85$ & Bleeding was stopped \\
\hline $7^{\mathrm{a}}$ & $\mathrm{Pl}$ & Splx & $?$ & Splx without complications \\
\hline $8(?)$ & $?$ & $?$ & $40-140(2-4 h)^{\mathrm{b}} ?$ & $?$ \\
\hline $9(\mathrm{Jw})$ & Pred, Cycloph & Bleeding & 90 & Bleeding was stopped \\
\hline $10^{\mathrm{a}}(?)$ & $?$ & $?$ & $?$ & $?$ \\
\hline 11 & IVIgG, Dexa, Pl & $\mathrm{ICH}$ & $2 \times 90$ & $2 \times$ bleeding was stopped \\
\hline 12 & Pl, FFP, Tranex & $\mathrm{ICH}$ & $\begin{array}{l}122 /(2 \mathrm{~h})^{\mathrm{b}}, 122(4-8 \mathrm{~h})^{\mathrm{b}} 3 \text { weeks, } \\
122 /(\text { daily }) 5 \text { days }\end{array}$ & No further hemorrhage \\
\hline 13 & $\begin{array}{l}\text { Plasmaph, IVIgG, Steroids, } \\
\text { Cycloph, FFP, RBCs }\end{array}$ & Bleeding & $?$ & $\begin{array}{l}\text { Bleeding was stopped, but the } \\
\text { patient died }\end{array}$ \\
\hline 14 & Splx, Tranex, Desmo, Pl & Splx & $3 \times 40-70$ & $\begin{array}{l}\text { No major bleeding during } \\
\text { Splx }\end{array}$ \\
\hline 15 & Anti-CD20/Splx & Splx & $3 \times 40-70$ & $\begin{array}{l}\text { No complication occurred } \\
\text { post Splx }\end{array}$ \\
\hline 16 & Pl, Aminocaproic acid & Postoperative bleeding & $\begin{array}{l}2 \times 90 /(2 \mathrm{~h})^{\mathrm{b}}, 90 /(4 \mathrm{~h})^{\mathrm{b}} \text { day } 1,90 / \\
(6 \mathrm{~h})^{\mathrm{b}} \text { day } 2\end{array}$ & Bleeding was stopped \\
\hline 17 & Pl, Desmo, Cry, RBCs & Postoperative bleeding & $9 \times 101 /$ daily, $1 \times 50.5$ & died \\
\hline 18 & & $\begin{array}{l}\text { Tranex, fibrin, wisdom teeth } \\
\text { extraction with osteotomy }\end{array}$ & $\begin{array}{l}1 \times 1120 \text { (bolus), } 2 \times 120(2 \text { and } 6 \mathrm{~h} \\
\text { after OP) }\end{array}$ & No major bleeding \\
\hline
\end{tabular}

Pl Platelet transfusion, $R B C s$ red blood cell transfusion, FFP fresh frozen plasma, Cry cryoprecipitate, Splx Splenectomy, Vinc vincristine, $M P$ methylprednisolone, Dexa dexamethasone, aa aminocaproic acid, Tranex tranexamic acid, Cycloph cyclophosphamide, BMT bone marrow transplantation, plasmaph plasmapheresis, Desmo desmopressin, $I C H$ intracranial hemorrhage, op operation, $J w$ Jehovas witness

${ }^{\text {a }}$ Text not in English

${ }^{b}$ Every $\times$ hours

administered to the patients immediately following or even during the administration of other agents that may also lead to a rapid increase in platelet counts and/or a rapid reduction of bleeding, i.e., IVIgG, steroids, platelet transfusion, tranexamic acid, desmopressin, or aminocaproic acid, respectively. Thus, the effect observed in all responsive patients and cases can not be solely attributed to rFVIIa.

On the other hand, there are a number of reports describing the successful use of rFVIIa to stop bleeding in patients with nonimmune thrombocytopenia $[20,27,28$, 42]. These studies indicate that rFVIIa is effective in the treatment of bleeding in patients with thrombocytopenia and/or thrombocytopathy, without a combination with other hemostatic agents. Therefore, it is probable that rFVIIa may improve hemostasis and stop bleeding in patients with ITP.

The mechanism by which rFVIIa stops bleeding in these patients remains unclear. In vitro experiments have demonstrated that high concentrations of FVIIa induce platelet activation, generate platelet surface factor IXa and Xa which lead to thrombin generation on the platelet surface, and also to the formation of hemostatic plaque despite low platelet numbers [22, 34]. Moreover, very high concentrations of rFVIIa may also result in a saturation of all available tissue factor exposed at the site of injury, as well as in extravascular spaces, leading to local thrombin generation and thrombus formation [38]. These processes appear to occur without systemic activation of blood coagulation in treated patients [24, 39]. Based on these findings, it is not surprising that rFVIIa may also help patients with ITP and uncontrolled bleeding. Whatever the mechanism may be, further advanced studies are required in order to determine the optimal dosage required and to clarify its true effect in this group of patients. 


\section{Concluding remarks}

Although infrequent, the phenomenon that platelet counts may gradually, rapidly, or even abruptly increase in ITP patients who seem to be absolutely refractory to available therapies is well known. This is particularly the case when the affected patients receive a mixture of different drugs that may either solely or in combination increase the platelet count and/or improve hemostasis in bleeding patients. Although it is extremely difficult to retain restraint for bleeding patients, the physicians involved in the treatment of such patients should avoid in administering a combinations of drugs. In addition, future studies need to address the question as to whether rFVIIa alone is effective in the treatment of patients with ITP and uncontrolled bleeding. There are several possibilities which may help in answering this major question: (1) patients who would be treated with rFVIIa must be selected, i.e., patients who present with active bleeding that would be compensated without any serious complications if rFVIIa administration is not successful, (2) circumventing the administration of drug mixtures that do not allow for an accurate interpretation of hemostatic results, (3) the interval of administered drugs should be extended as much as possible to obtain somewhat authentic results, and (4) it is paramount that all treated patients with ITP be described, not only successfully treated patients. Only by doing so then can we be able to provide a proper and legitimate recommendation for the use of rFVIIa in ITP.

\section{References}

1. Abrahm J, Ellman L (1976) Platelet transfusion in immune thrombocytopenic purpura. JAMA 236:1847 doi:10.1001/ jama.236.16.1847a

2. Aguilar C, Lucía JF (2007) Successful control of severe postoperative bleeding with recombinant factor VIIa in a case of refractory idiopathic thrombocytopenic purpura. Am J Hematol 82:246-247 doi:10.1002/ajh.20728

3. Barnes C, Blanchette V, Canning P, Carcao M (2005) Recombinant FVIIa in the management of intracerebral haemorrhage in severe thrombocytopenia unresponsive to platelet-enhancing treatment. Transfus Med 15:145-150 doi:10.1111/j.09587578.2005.00564.x

4. Baumann MA, Menitove JE, Aster RH, Anderson T (1986) Urgent treatment of idiopathic thrombocytopenic purpura with single-dose gammaglobulin infusion followed by platelet transfusion. Ann Intern Med 104:808-809

5. Baxter MS, Schroeder WS, Cheng Y, Bernstein ZP (2006) Diminished response to recombinant factor VIIa in a patient with idiopathic thrombocytopenic purpura. Ann Pharmacother 40:2053-2058 doi:10.1345/aph.1H331

6. Bay A, Oner AF, Etlik O, Caksen H (2005) A case of immune thrombocytopenic purpura presenting with recurrent intracranial hemorrhage. Pediatr Int 47:109-111 doi:10.1111/j.1442200x.2005.02014.x
7. Blanchette V, Freedman J, Garvey B (1998) Management of chronic immune thrombocytopenic purpura in children and adults. Semin Hematol 35:36-51

8. Busani S, Marietta M, Pasetto A, Girardis M (2005) Use of recombinant factor VIIa in a thrombocytopenic patient with spontaneous intracerebral haemorrhage. Thromb Haemost 93:381-382

9. Bussel JB, Kimberly RP, Inman RD, Schulman I, CunninghamRundles C, Cheung $\mathrm{N}$ et al (1983) Intravenous gammaglobulin treatment of chronic idiopathic thrombocytopenic purpura. Blood 62:480-486

10. Carr JM, Kruskall MS, Kaye JA, Robinson SH (1986) Efficacy of platelet transfusions in immune thrombocytopenia. Am J Med 80:1051-1054 doi:10.1016/0002-9343(86)90664-9

11. Chandramouli NB, Rodgers GM (2000) Prolonged immunoglobulin and platelet infusion for treatment of immune thrombocytopenia. Am J Hematol 65:85-86 doi:10.1002/1096-8652(200009) $65: 1<85::$ AID-AJH17>3.0.CO;2-9

12. Cines DB, Blanchette VS (2002) Immune thrombocytopenic purpura. N Engl J Med 346:995-1008 doi:10.1056/ NEJMra010501

13. Cines DB, McMillan R (2005) Management of adult idiopathic thrombocytopenic purpura. Annu Rev Med 56:425-442 doi:10.1146/annurev.med.56.082103.104644

14. Crosby WH (1975) Editorial: wet purpura, dry purpura. JAMA 232:744-745 doi:10.1001/jama.232.7.744

15. Culic S (2002) Recombinant factor VIIa for refractive haemorrhage in autoimmune idiopathic thrombocytopenic purpura. Br J Haematol 120:909-910 doi:10.1046/j.1365-2141.2003.04151_2.x

16. Frederiksen H, Schmidt K (1999) The incidence of idiopathic thrombocytopenic purpura in adults increases with age. Blood 94:909-913

17. Friederich PW, Henny CP, Messelink EJ, Geerdink MG, Keller T, Kurth $\mathrm{KH}$ et al (2003) Effect of recombinant activated factor VII on perioperative blood loss in patients undergoing retropubic prostatectomy: a double-blind placebo-controlled randomised trial. Lancet 361:201-205 doi:10.1016/S0140-6736(03)12268-4

18. George JN, Woolf SH, Raskob GE, Wasser JS, Aledort LM, Ballem PJ et al (1996) Idiopathic thrombocytopenic purpura: a practice guideline developed by explicit methods for the American Society of Hematology. Blood 88:3-40

19. Gerotziafas GT, Zervas C, Gavrielidis G, Tokmaktsis A, Hatjiharissi E, Papaioannou M et al (2002) Effective hemostasis with rFVIIa treatment in two patients with severe thrombocytopenia and life-threatening hemorrhage. Am J Hematol 69:219-222 doi:10.1002/ajh.10056

20. Goodnough LT (2004) Experiences with recombinant human factor VIIa in patients with thrombocytopenia. Semin Hematol 41:25-29 doi:10.1053/j.seminhematol.2003.11.006

21. Hadacova I, Hoch J (2003) Activated factor VII as the perioperative guarrancy of splenectomy for severe form of corticoresistant ITP. Prakt Lek 83:695-696

22. Hoffman M, Monroe DM, Roberts HR (1998) Activated factor VII activates factors IX and X on the surface of activated platelets: thoughts on the mechanism of action of high dose activated FVII. Blood Coagul Fibrinolysis 9:S61-S65

23. Imbach P, Barandun S, D'Apuzzo V, Baumgartner C, Hirt A, Morell A et al (1981) High-dose intravenous gammaglobulin for idiopathic thrombocytopenic purpura in childhood. Lancet 1:1228-1231 doi:10.1016/S0140-6736(81)92400-4

24. Ingerslev J, Holm M, Christiansen K, Knudsen L, Négrier C (1998) Levels of prothrombin activation peptide F1 2 in patients with bleeding tendency. Blood Coagul Fibrinolysis 9:S129-S134 doi:10.1097/00001721-199803000-00003

25. Kiefel V, Santoso S, Kaufmann E, Mueller-Eckhardt C (1991) Autoantibodies against platelet glycoprotein lb/IX: a frequent 
finding in autoimmune thrombocytopenic purpura. Br J Haematol 79:256-262 doi:10.1111/j.1365-2141.1991.tb04530.x

26. Klamroth R, Gottstein S, Landgraf H (2002) Successful use of recombinant factor VIIa to prevent bleeding during major surgery in a patient with severe immune thrombocytopenia. Blood $100: 77 b$

27. Kristensen J, Killander A, Hippe E, Helleberg C, Ellegard J, Holm $M$ et al (1996) Clinical experience with recombinant factor VIIa in patients with thrombocytopenia. Haemostasis 26:159-164

28. Kubisz P, Stasko J (2004) Recombinant activated factor VII in patients at high risk of bleeding. Hematology 9:317-332 doi:10.1080/10245330400018581

29. Levi M, Peters M, Büller HR (2005) Efficacy and safety of recombinant factor VIIa for treatment of severe bleeding: a systematic review. Crit Care Med 33:883-890 doi:10.1097/01. CCM.0000159087.85970.38

30. McMillan R, Tani P, Millard F, Berchtold P, Renshaw L, Woods VL Jr (2005) Platelet-associated and plasma anti-glycoprotein autoantibodies in chronic ITP. Blood 70:1040-1045

31. McMillan R (1997) Therapy for adults with refractory chronic immune thrombocytopenic purpura. Ann Intern Med 126:307-314

32. Meyer O, Agaylan A, Bombard S, Kiesewetter H, Salama A (2006) A novel antigen-specific capture assay for the detection of platelet antibodies and HPA-1a phenotyping. Vox Sang 91:324330 doi:10.1111/j.1423-0410.2006.00839.x

33. Minniti C, Weinthal J (2001) Use of recombinant activated factor VII (rFVIIa) in two children with idiopathic thrombocytopenic purpura (ITP). Blood 98:62b

34. Monroe DM, Hoffman M, Oliver JA, Roberts HR (1997) Platelet activity of high dose factor VIIa is independent of tissue factor. Br J Haematol 99:542-547 doi:10.1046/j.1365-2141.1997.4463256.x

35. Morath C, Hoffmann T, Kirchhoff EM, Sis J, Zeier M, Scharf RE et al (2005) Acquired Glanzmann's thrombasthenia variant and immune thrombocytopenia in a renal transplant recipient receiving tacrolimus. Thromb Haemost 94:879-880

36. Portielje JEA, Westendorp RGJ, Kluin-Nelemans HC, Brand A (2001) Morbidity and mortality in adults with idiopathic thrombocytopenic purpura. Blood 97:2549-2554 doi:10.1182/blood. V97.9.2549

37. Provan D, Newland A (2002) Fifty years of idiopathic thrombocytopenic purpura (ITP): Management of refractory
ITP in adults. Br J Haematol 118:933-944 doi:10.1046/j.13652141.2002.03669.x

38. Rao LVM, Williams T, Rapaport SI (1996) Studies on the activation of factor VII bound to tissue factor. Blood 87:37383748

39. Roberts HR (1998) Clinical experience with activated factor VII: focus on safety aspects. Blood Coagul Fibrinolysis 9:S115-S118

40. Serban M, Petrescu CAM, Jinca C, Mihalov D (2003) Evaluation of the rFVIIa efficacy in children's haemorrhages of different etiology. J Thromb Haemost 1(Suppl.):1144 doi:10.1046/j.15387836.2003.00144.x

41. Van Leeuwen EF, van der Ven JT, Engelfriet CP, von dem Borne AE (1982) Specifity of autoantibodies in autoimmune thrombocytopenia. Blood 59:23-36

42. Vidarsson B, Onundarson PT (2000) Recombinant factor VIIa for bleeding in refractory thrombocytopenia. Thromb Haemost 83:634-635

43. Virchis A, Hughes C, Berney S (2004) Severe gastrointeral haemorrhage responding to recombinant factor VIIa in a Jehova's Witness with refractory immune thrombocytopenia. Hematol J 5:281-282 doi:10.1038/sj.thj.6200395

44. Vyhovs'ka II, Karol' IS, Fedak LM, Tsytsyk OI (2004) Use of recombinant activated factor VII (NovoSeven) in the treatment of a patient with idiopathic thrombocytopenic purpura complicated with subarachnoid and parenchimatous hemorrhage. Lik Sprava 7:77-81

45. Waddington DP, McAuley FT, Hanley JP, Summerfield GP (2002) The use of recombinant factor VIIa in a Jehovah's witness with auto-immune thrombocytopenia and post-splenectomy haemorrhage. Br J Haematol 119:286-288 doi:10.1046/j.13652141.2002.381113.x

46. Wróbel G, Dobaczewski G, Patkowski D, Sokół A, Grotthus E (2006) Experiences with recombinant activated factor VII in the treatment of severe refractory thrombocytopenia. Pediatr Blood Cancer 47:729-730 doi:10.1002/pbc.21013

47. Yoneoka Y, Tokita K, Yamauchi JI, Takeda N, Ohta H, Shindo T (2004) Successful management for spontaneous intracranial haemorrhage under critical thrombocytopenia (platelets $<1000$ / $\mathrm{mm}(3)$ ) due to adolescence-onset idiopathic thrombocytopenic purpura. Acta Neurochir (Wien) 146:199-201 doi:10.1007/ s00701-003-0185-0 